\title{
Histological Evaluation of Allium sativum Oil as a New Medicament for Pulp Treatment of Permanent Teeth
}

\author{
${ }^{1}$ Shukry Gamal Mohammad, ${ }^{2}$ Syed Ahmed Raheel, ${ }^{3}$ Kusai Baroudi
}

\begin{abstract}
Objective: The objective of this study was to evaluate the histopathology effects of two medicaments Allium sativum oil and formocresol on the remaining pulp tissue of the permanent teething children.
\end{abstract}

\begin{abstract}
Materials and methods: A total of 18 premolars were included in this study. Two sound premolars were extracted and subjected to histological examination to show the normal pulp tissue. Pulpotomy procedure was performed in the rest of the remaining 16 premolars; half of them using Allium sativum oil and the rest of the tested premolars were medicated using formocresol and all were sealed with suitable restoration. Then, premolars extracted at variable intervals (48 hours, 2 weeks, 1 month, 2 months), stained using hemotoxylin and eosin etain (H\&E) and prepared for histopathology examination.
\end{abstract}

Results: Histological evaluation seemed far more promising for Allium sativum oil than formocresol. Histological evaluation revealed that teeth treated with Allium sativa oil showed inflammatory changes that had been resolved in the end of the study. On the contrary, the severe chronic inflammation of pulp tissue accompanied with formocresol eventually produced pulp necrosis with or without fibrosis. In addition, pulp calcification was evidenced in certain cases.

Conclusion: Allium sativum oil is a biocompatible material that is compatible with vital human pulp tissue. It offers a good healing potential, leaving the remaining pulp tissue healthy and functioning.

Keywords: Allium sativum oil, Formocresol, Pulpotomy.

How to cite this article: Mohammad SG, Raheel SA, Baroudi K. Histological Evaluation of Allium sativum Oil as a New Medicament for Pulp Treatment of Permanent Teeth. J Contemp Dent Pract 2015;16(2):85-90.

\footnotetext{
${ }^{1}$ Department of Restorative Dental Sciences, Al-Farabi College, Riyadh, Saudi Arabia; Department of Pediatric Dentistry, School of Dentistry, Al-Azhar University, Egypt

${ }^{2}$ Department of Oral and Maxillofacial Sciences, Al-Farabi College of Dentistry and Nursing, Riyadh, Saudi Arabia

${ }^{3}$ Department of Restorative Dental Sciences, Al-Farabi College of Dentistry and Nursing, Riyadh, Saudi Arabia

Corresponding Author: Kusai Baroudi, Assistant Professor Department of Restorative Dental Sciences, Al-Farabi College of Dentistry, Riyadh-11691, PO Box: 85184, Saudi Arabia, Fax: +96612324580, Phone 00966-12273151, e-mail: d_kusai@ yahoo.co.uk
}

\section{Source of support: Nil \\ Conflict of interest: None}

\section{INTRODUCTION}

Preservation of the remaining vital portion of curiously exposed pulpal tissue in primary teeth, where the demand is to keep a functioning tooth in site, was one of the most frequent problems in pediatric dentistry. ${ }^{1}$ To solve this problem pulpotomy therapy was introduced, developed and classified according to treatment objectives. ${ }^{2}$ Pulpotomy involves amputation of the coronal portion of affected or infected dental pulp,treatment of the remaining vital radicular pulp tissue surface should preserve the vitality and function of all or part of the remaining radicular portion of the pulp. ${ }^{3}$ Furthermore, it is an accepted procedure for treating both primary and permanent teeth with carious pulp exposures, several materials have been use for capping the radicular pulp after pulpotomy, these included formocresol, glutaraldehyde, ferric sulfate, collagen material, and mineral trioxide aggregate. ${ }^{4}$

However, none of them had met the same degree of effectiveness and success rate as formocresol, possible hazards of formocresol (cytotoxicity, carcinogenicity, immunologic, biochemical, mutagenic and teratogenic changes) in the host have been reported. ${ }^{5}$ Moreover, it produced enamel defects in the permanent successors. ${ }^{6}$ In this regard, a demand for natural medicament to replace formocresol as a pulp dressing material became imperative.

Allium sativum is one of the most extensively researched medicinal plants and its antibacterial activity depends on allicin produced by enzymatic activity of allinase (a cysteine sulfoxidelyase). Allicin and other thiosulfinates are believed to be responsible for the range of therapeutic effects reported for garlic; there is extensive literature on antibacterial effects of fresh garlic extract. ${ }^{7}$ Garlic extract has been reported to inhibit growth of various gram-positive and gram-negative bacteria. ${ }^{8}$

Allium sativum extract has been known to have inhibitory activity on various pathogenic bacteria, viruses and fungi. There is inhibitory activity of garlic extract on multidrug-resistant (MDR) strains of Streptococcus mutans isolated from human carious teeth. ${ }^{9}$ 


\section{AIM OF THE STUDY}

The aim of this study was to evaluate the histopathology effects of two medicaments Allium sativum oil and formocresol on the remaining pulp tissue of the permanent teeth in children.

\section{MATERIALS AND METHODS}

A total of 18 premolars were included in this study, obtained from nine patients; six girls and three boys. The patients were aged between 14 and 18 years. The teeth utilized in this study were limited to premolars, which required exodontias in the course of orthodontic treatment.

Ethical approval of the study: Informed consent was obtained. Approval of Al-Azhar University, faculty of oral and dental medicine, Egypt (under number 249/2010) was also obtained.

Two sound premolars were extracted without pulpotomy procedure and subjected to histological examination to show the normal pulp tissue. Pulpotomy procedure was performed in the rest of the remaining 16 premolars. Eight teeth with each material; then capping the radicular pulp with small cotton pellet medicated with Alliums sativa oil (Captin company (CAP pharm) registration No 952/94 Cairo, Egypt) of premolar in one side, and other side with formocresol (Petrópolis-RJIndustria Brasileira, Dentsply, Latin America) and sealed with suitable restoration. Then premolars extracted at variable intervals ( 48 hours, 2 weeks, 1 month, 2 months) then divide to:

\section{1-Group A}

Premolars are medicated with Allium sativum oil and subdivided to four subgroups:

\section{Subgroup A1}

Treated with Allium sativum oil and extracted for histological examination after 48 hours.

\section{Subgroup A2}

Treated with Allium sativum oil and extracted for histological examination after 2 weeks.

\section{Subgroup A3}

Treated with Allium sativum oil and extracted for histological examination after 1 month.

\section{Subgroup A4}

Treated with Allium sativum oil and extracted for histological examination after 2 month.

\section{2-Group B}

Premolars are medicated with formocresol and subdivided to four subgroups:

\section{Subgroup B1}

Treated with formocresol and extracted for histological examination after 48 hours.

\section{Subgroup B2}

Treated with formocresol and extracted for histological examination after 2 weeks.

\section{Subgroup B3}

Treated with formocresol and extracted for histological examination after 1 month.

\section{Subgroup B4}

Treated with formocresol and extracted for histological examination after 2 month.

Then fixed in 10\% buffered formalin and stained by standard hematoxylin and eosin (H\&E) stain, then examined under a bright field microscope.

\section{RESULTS}

\section{1-Group A}

Premolars are medicated with Allium sativum oil:

\section{Subgroup A1}

The capped material-pulp tissue interface showed degeneration of the pulp cells and a replacement by an inflammatory cell. Numerous vascular spaces filled with erythrocytes, some of them had coagulation in addition to tissue fibers. The remainder of the pulp tissue showed the odontoblastic layer outlined the pulp tissue on one side and an absence of them on the other side at the pulp-dentin junction. Void spaces throughout interstitial edema and hyperemia throughout the pulp (Fig. 1).

\section{Subgroup A2}

The capped material-pulp issue interface revealed inflammatory cell, pulp tissue fibrosis and numerous dilated and congested blood vessels containing blood cells. Accumulation of fluid has taken place within the cytoplasm of the odontoblasts giving them a vacuolated appearance. The central part showed the same alteration, in addition to a hyalinization of connective tissue stroma and vacuolization of the odontoblasts. The remainder of the pulp tissue showed large and dilated blood vessels and microabscess formation (Fig. 2). 


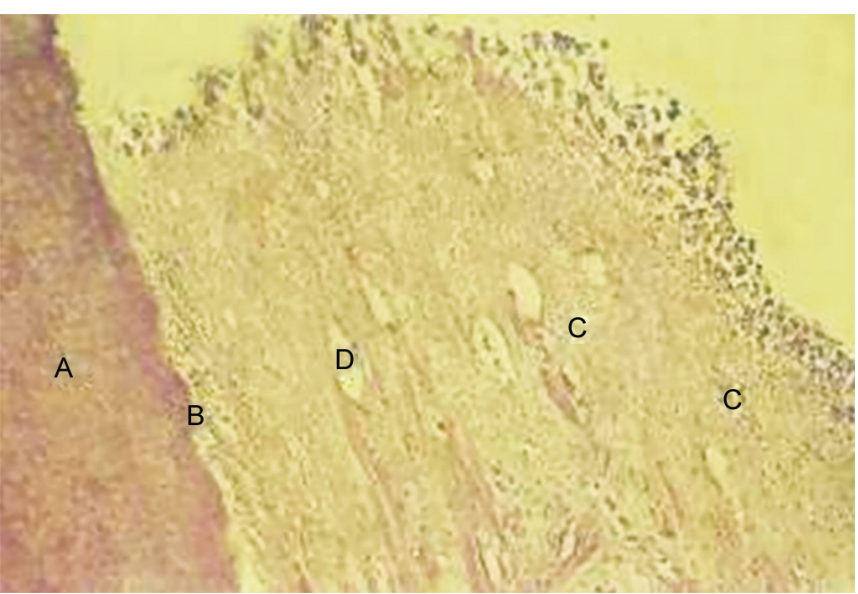

Fig. 1: Histological section of a tooth in subgroup A1 showing; (A) dentin, (B) an absence of odontoblasts, (C) inflammatory cell, (D) vascular spaces

\section{Subgroup A3}

The capped material-pulp tissue interface revealed odontoblast outlined the pulp. In addition, numerous vascular spaces throughout a loose pulpal connective tissue stroma, granulation tissue and calcified masses were observed. These calcified masses were found near

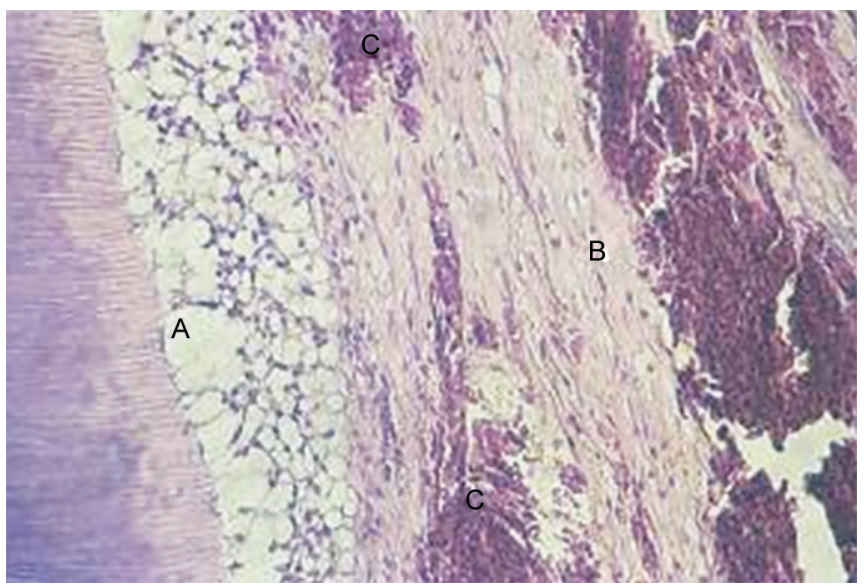

Fig. 2: Histological section of a tooth in subgroup A2 showing; (A) vacuolization of odontoblasts, $(B)$ hyalinization of pulpal connective tissue, (C) foci of polymorph nuclear leukocytes

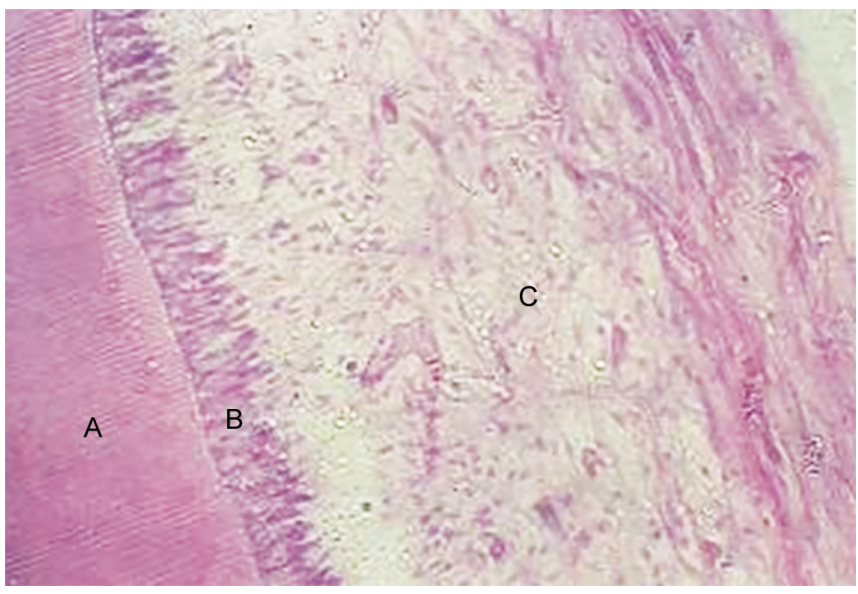

Fig. 4: Histological section of a tooth in subgroup A4 showing; (A) dentin, (B) odontoblasts, (C) pulpal connective tissue stroma to the capped material-pulp tissue interface at the pulpdentin junction. Inflammatory cell infiltrate was seen. The remainder of the pulp tissue at the deeper part showed a regular pattern of the odontoblastic layer (Fig. 3).

\section{Subgroup A4}

The capped material-pulp tissue interface revealed, the superficial part of the pulp tissue had odontoblasts and fibroblasts. The odontoblastic layer showed a continuous regular arrangement at the pulp dentin junction in addition to a loose febrile connective tissue stoma. The remainder of the pulp tissue showed a regular pattern of the odontoblastic layer (Fig. 4).

\section{2-Group B}

Premolars are medicated with formocresol:

\section{Subgroup B1}

The capped material-pulp tissue interface revealed the superficial region; fibrotic pulpal tissue formation subjacent to layers of well-formed odontoblasts. The

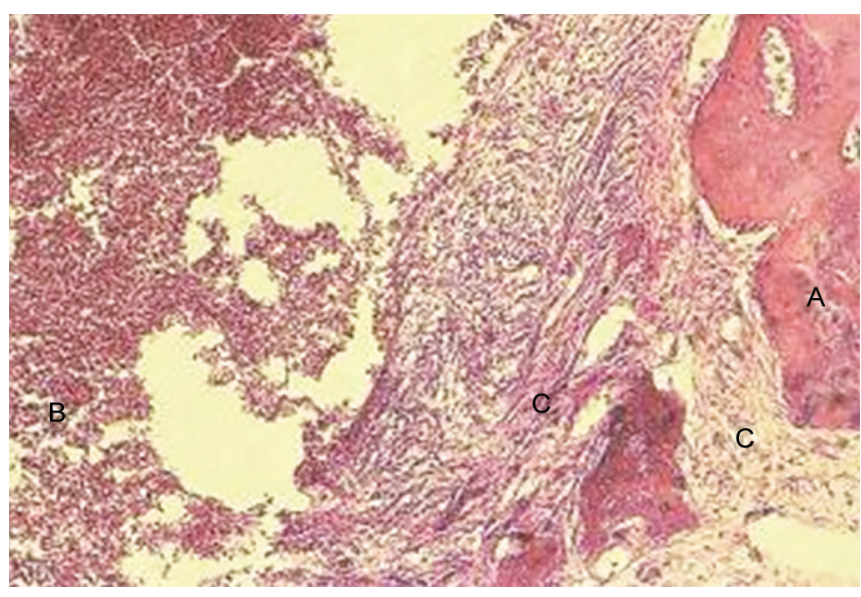

Fig. 3: Histological section of a tooth in subgroup A3 showing; (A) osteodentin, (B) inflammatory cell infiltrates, (C) connective tissue fibers

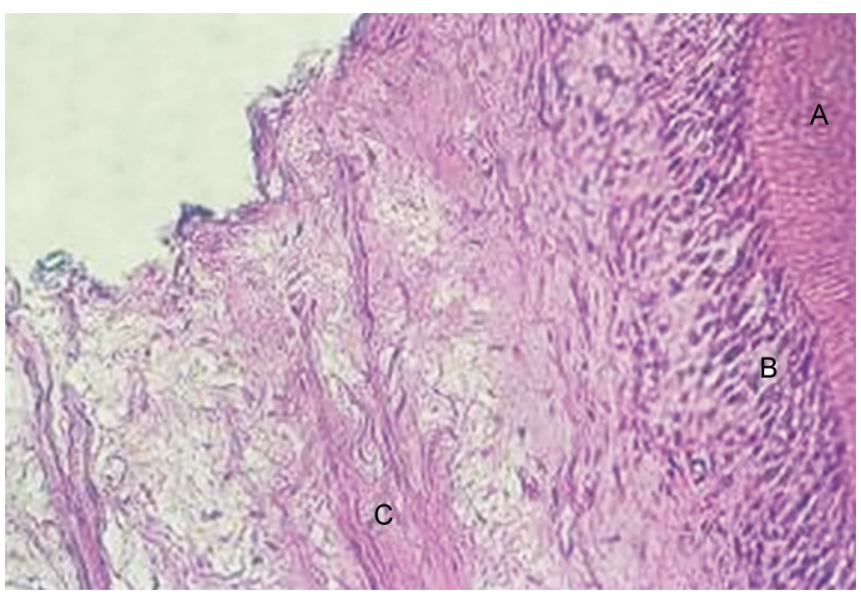

Fig. 5: Histological section of a tooth in subgroup B1 showing; $(A)$ dentin, (B) odontoblasts, $(C)$ hyalinized connective tissue stroma 
odontoblasts showed hyperplasia. The central part showed hyalinized and coagulative connective tissue stroma. The remainder of the pulp tissue showed hyalinization, interstitial edema with numerous void spaces (Fig. 5).

\section{Subgroup B2}

The capped material-pulp tissue interface revealed, the superficial region degenerative and atrophic changes of odontoblastic layers, pulpal hyperemias with thrombus formation were seen, a well-formed bridge of odontoblasts and fibroblast, and hyperplasia of odontoblasts. The central part showed a loosely fibrillar connective stroma (Fig. 6).

\section{Subgroup B3}

The capped material-pulp tissue interface revealed a hyalinized structureless zone and odontoblasts at the pulp dentin junction. The pulpal connective tissue showed masses of dense bundles of connective tissue fibers throughout a loosely connective tissue and pulp calcifications. The remainder of the pulp tissue showed odontoblastic layer at the pulp-dentin junction. The pulpal connective tissue showed the same pattern of the superficial part (Fig. 7).

\section{Subgroup B4}

The capped material-pulp tissue interface revealed the superficial part zone of a coagulated fixative homogenous eosinophilia mass, A hyalinized structureless zone: the central part of the pulp degenerative changes in both odontoblasts and the connective tissue vacuolization of the odontoblasts, and intercellular edema in the connective tissue stroma. The radicular pulp showed calcified masses. The peripheral odontoblasts showed a reduction in size of the nuclei with condensation. Degenerative changes of peripheral odontoblasts at the pulp-dentin junction have highly vascularized connective tissue with thrombus formation (Fig. 8).

\section{DISCUSSION}

In the present study, histological findings that were seen in the remaining pulp tissue, which might be due to trauma of the pulp from pulpotomy procedure were gradually resolved. A replacement by regenerative tissues began to appear through a regular arrangement of the pulp tissue at one-month interval. A regular pattern of the odontoblastic layer that outlined the pulp tissue at the pulp-dentin junction was seen. An improvement of the pulp tissue similar to the normal pattern was seen at 2 months. These dramatic changes reveal the

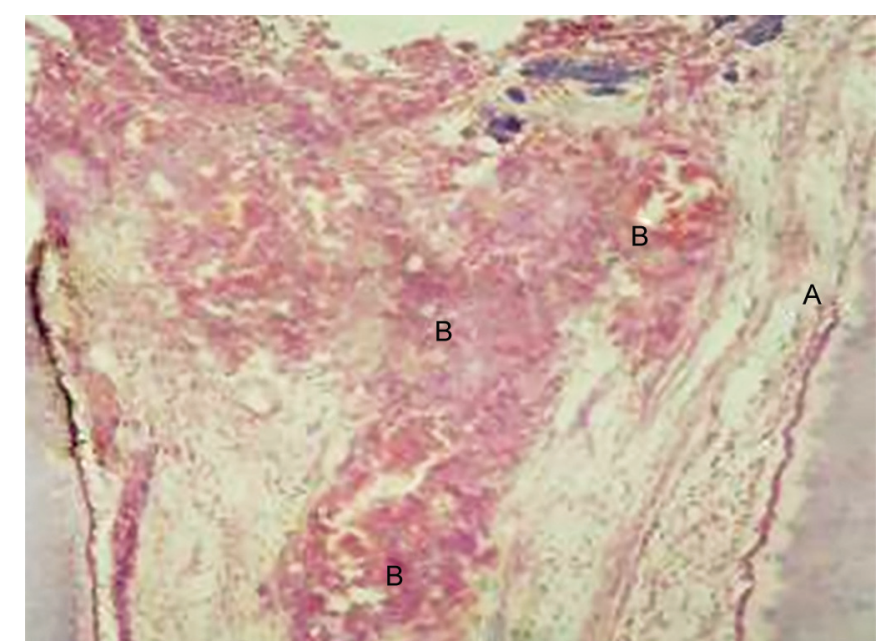

Fig. 6: Histological section of a tooth in subgroup B2 showing; (A) atrophy of odontoblastic layers, (B) pulpal hyperemia with thrombus

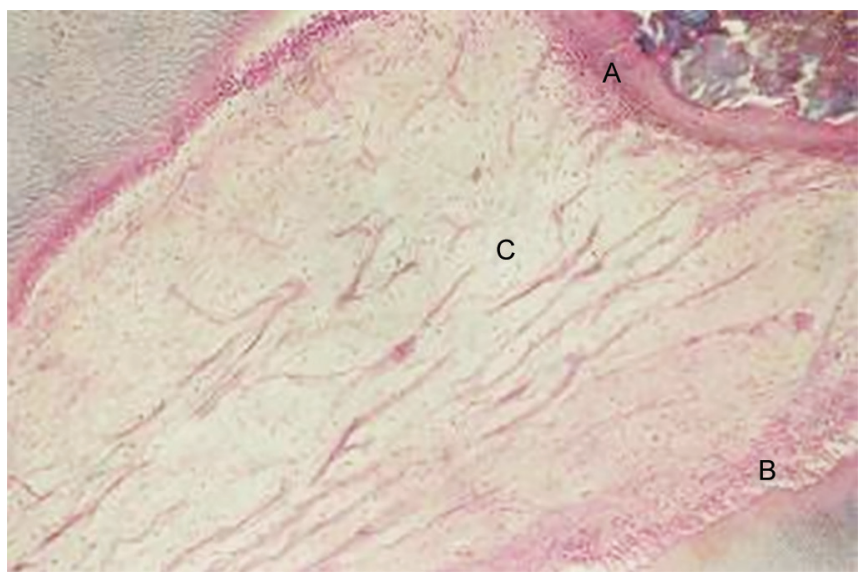

Fig. 7: Histological section of a tooth in subgroup B3 showing; (A) hyalinized structureless zone, (B) odontoblasts, (C) a loosely pulpal connective tissue stroma

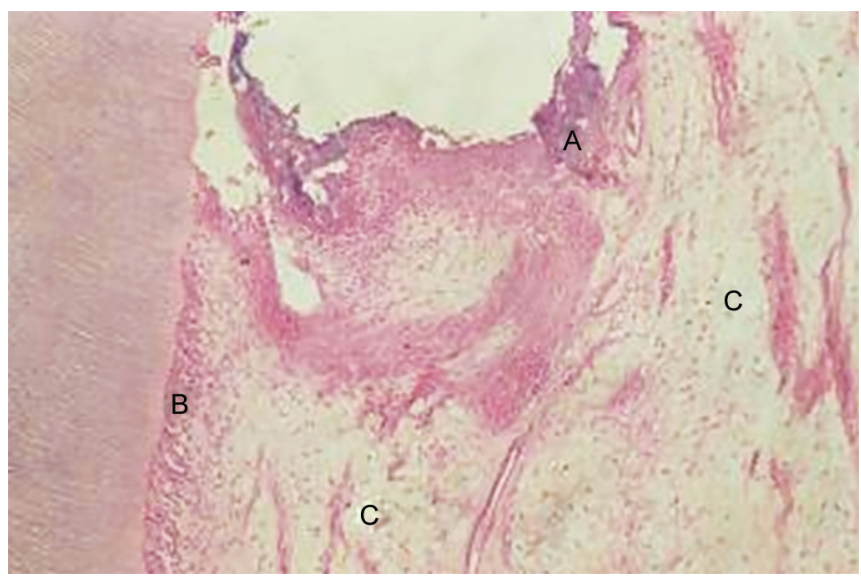

Fig. 8: Histological section of a tooth in subgroup B4 showing; (A) hyalinized structureless zone, (B) odontoblasts, (C) interstitial edema

healing power of Alium sativum oil that might indicate its biocompatibility. This can be explained on the basis of its immune protective and immune potentiating effect as Allium sativa oil augments the T cell and natural killer cell-mediated immune responses and stimulates 
macrophage phagocytic activity either directly or via activation of lymphocytes. ${ }^{10}$

One of the most striking features in specimens of Allium sativum oil was the appearance of osteodentin, the presence of osteodentin at the pulp-connective tissue interface which might be due to the rate of the deposition of normal dentin, which might be too slow to seal off the pulp tissue, thus requiring a more rapidly formed calcified tissue, osteodentin. Some investigators doubted that degenerating odontoblasts could produce osteodentin. Odontoblasts lost their processes and became osteoblasts. ${ }^{11}$

No structural differences were existed between primary pulp tissue and permanent pulp tissue. ${ }^{12}$ In addition, the pulpal dentinal complex response to dental caries in human primary teeth was described by earlier investigators as being similar to that seen in permanent teeth. ${ }^{13}$

Because the premolars used in the histologic study were planned for extraction in the course of orthodontic treatment, they needed to be extracted after 2 months. Therefore, the longer period of the histopathologic investigation was limited to 2 months. The histologic features observed at that time were used as an indicator of the relative efficacy of the examined medicaments. Therefore, further researches of longer period are recommended. The usual histological finding in vital pulp after application of formocresol is a zone of necrosis followed by a zone of fixation. Beyond this, there is an inflammatory infiltrate, which gradually leads to normal pulp. Healing without inflammation is not seen with formocresol. Replacement of inflammation and necrosis with granulation tissue and bone or osteodentin has also been reported. ${ }^{14}$

In the present study, histological examination of the decalcified teeth treated with formocresol at 48 hours period, a fibrotic pulpal tissue formatin subjacent to layers of well-formed odontoblasts were seen. While, at 1-month interval tissue at the capped material-pulp tissue interface revealed a hyalinized structure less zone. This peculiar finding was interpreted as fixation, the formocresol acting as a protein coagulant. The histochemical study using subcutaneous sponge implants in rats supports this interpretation; formocresol apparently suppresses metabolism and acts as a cytotoxic agent. At one and two month intervals, pulpal connective tissue stroma showed normal pattern except the presence of irregular bundles of connective tissue fibers, some of them showing hyalinization. In addition, masses of dense bundles of connective tissue fibers were present. As an explanation of this finding is that formocresol had penetrated the pulp tissue a few millimeters in a apical direction, resulting in a partial fixation of the pulp tissue. The formocresol- fixed pulp tissue probably has an effect on the subjacent pulp tissue, which may result in a hyaline degeneration or fibrosis. ${ }^{15}$

The connective tissue stroma was highly vascularized. Pulpal hyperemia with thrombus formation was, also, seen. This finding can be interpreted on the basis that formaldehyde penetration into vessels caused their fixation, since formaldehyde diffusion is faster 5 times in blood plasma than in tissues. ${ }^{16}$

Pulp calcifications were seen at 1 month interval. In addition, at 2 months interval, the radicular pulp showed calcified masses with different sizes. This finding was in accordance with previous studies. ${ }^{17}$ It should be realized that in the pulp, as elsewhere in the body, dead or degenerating tissue might become impregnated with calcium salts. This represents a pathological condition. ${ }^{18}$ Amorphous reactionally dentin formation is a sign or consequence of attempted repair processes within the pulp tissue. Perhaps after an initial attempt by the pulp tissue to wall-off' insult, the protective or reactive process failed. ${ }^{19}$

\section{CONCLUSION}

Allium sativum oil is a biocompatible material that is compatible with vital human pulp tissue. It offers a good healing potential, leaving the remaining pulp tissue healthy and functioning. So, it could be used successfully as a medicament for pulpotomy treatments.

\section{REFERENCES}

1. Primosch R, Glomb T, Jerrell R. Primary tooth pulp therapy as taught in pediatric dental program in the United States. Pediat Dent 1997;19:118-122.

2. Hicks MJ, Barr ES, Flaitz CM. Formocresolpulpotomies in primary molars: a radiographic study in a pediatric dentistry practice. J Pedodont 1986;10:331-339.

3. Estrela C, Holland R, Bernabe PF, Souza V, Estrela CR. Antimicrobial potential of medicaments used in healing process in dog's teeth with apical periodontitis. Braz Dent J 2004;15:181-185.

4. Schwartz RS, Mauger M, Clement DJ, Walker W. Mineral trioxide aggregate: a new material for endodontics. J Am Dent Assoc 1999;130:967-975.

5. Myers DR, Shoaf HK, Dirksen TR, Pashley DH, Whitford GM, Reynolds KE. Distribution of 14C-formaldehyde afterpulpotomy with formocresol. J Am Dent Assoc 1978;96:805-813.

6. Lewis BB, Chestner SB. Formaldehyde in dentistry: a review of mutagenic and carcinogenic potential. JADA 1999;103: 429-434.

7. Tsao SM, Yin MC. In vitro antimicrobial activity of four diallylsulphides occurring naturally in garlic and Chinese leek oil. J Med Microbiol 2001;50:646-649.

8. Martin KW, Ernst E. Herbal medicines for treatment of bacterial infections: a review of controlled clinical trials. J Antimicrob Chemother 2003;51:241-246. 
9. Fani MM, Kohanteb J, Dayaghi M. Inhibitory activity of garlic (Allium sativum) extract on multidrug-resistant Streptococcus mutans. J Ind Soc Pedod Prev Dent 2007;25: 164-168.

10. Salman H, Bergman M, Bessler H, Punsky I, Djaldetti M. Effect of a garlic derivative (alliin) on peripheral blood cell immune responses. Int J Immunopharmacol 1999;21:589-597.

11. Bernick S. Vascular and nerve supply to the molar teeth of guinea pigs. J Dent Res 1996;45:249-260.

12. Fox CF, Heeley JD. Histologic study of human primary teeth. Arch Oral Biol 1980;25:103-110.

13. Cohen S, Massler M. Pulpal response to dental caries in human primary teeth. J Dent Child 1967;34:130-139.

14. Salako N, Joseph B, RitwikP,Salonen J, John P, Junaid TA. Comparison of bioactive glass, mineral trioxide aggregate, ferric sulfate, and formocresol as pulpotomy agents in rat molar. Dent Traumatol 2003;19:314-320.
15. Rölling I, Lampbjerg-Hansen H. Pulp condition of successfully formocresol-treated primary molars. Scand J Dent Res 1978;86:267-272.

16. Berger JE. A review of the erroneously labeled 'mummification' techniques of pulp therapy. Oral Surg Oral Med Oral Pathol 1972;34:131-144.

17. Cengiz SB, Batirbaygil Y, Atilla P, Asan E, Altay N, Chreli ZC. Histological comparison of alendronate, calcium hydroxide and formocresol in amputated rat molar. Dent Trauma 2005;21:281-288.

18. Block RM, Lewis D, Hirsch H, Coffey J, Langeland K. Systemic distribution of [14C]- labeled peraformaldehyde incorporated within formocresol following pulpotomies in doges. J Endo Dont 1983;9:176-189.

19. Waterhouse PJ, Nunn JH, Whitworth JM, Soames JV. Primary molar pulp therapy-histological evaluation of failure. In J Paediatr Dent 2000;10:313-321. 